\title{
Influence of microbial priming and seeding depth on germination and growth of native wildflowers
}

\author{
Daniela Barrera ${ }^{1}$, Juan Luera ${ }^{2}$, Kaitlynn Lavallee ${ }^{3}$ and Pushpa Soti ${ }^{*^{*}}$
}

\begin{abstract}
Background: Using native wildflowers for restoring marginal lands has gained considerable popularity. Establishment of wildflowers can be challenging due to several environmental factors. Restoring the microbial community in degraded habitats can potentially result in the native plant performance and habitat restoration. This study was conducted to investigate the impact of native soil microbes and seeding depth on germination of south Texas native wildflowers. Two wildflower species, Ratibida columnifera (Nutt.) (Mexican Hat) and Verbesina encelioides (Cav.) (cowpen daisy), were treated with microbial wash extracted from native soils, and germination rate was recorded for 14-day period. We further analyzed the growth, biomass allocation, and root colonization by mycorrhizal fungi in these two plants growing them in a plant growth chamber for 6 weeks. To determine the impact of seeding depth, we planted the seeds of the two plant species at 2-cm, $6-\mathrm{cm}$, and $12-\mathrm{cm}$ depth and monitored germination and plant growth.

Results: The two species responded differently to the seeding depth and microbial wash treatments. Microbial wash treatment resulted in higher germination rate in $R$. columnifera compared to control, while it did not have any impact on $V$. encelioides seed germination. While microbial treatment did not influence the total biomass, it had a significant impact on the biomass allocation in both the plant species. $R$. columnifera seeds germinated at both 2$\mathrm{cm}$ and $6-\mathrm{cm}$ depth and did not germinate at $12 \mathrm{~cm}$, while the $V$. encelioides seeds germinated only at $2 \mathrm{~cm}$ and did not germinate at 6-cm or 12-cm seeding depth.

Conclusions: While our results are species specific, our results indicate that native soil microbes can potentially improve the seed germination and growth of wildflowers. Our results also indicate the importance of specific seeding depth when sowing wildflower seeds for habitat restoration.
\end{abstract}

Keywords: Habitat restoration, Soil microbes, Seeding depth, Wildflowers, Root endophytes

\section{Introduction}

Fragmentation and loss of native habitats along with intensive agricultural practices have resulted in the loss of biodiversity of plants, insects, along with soil microbes contributing to cascading effects on the broader ecosystem (Biesmeijer et al. 2006; Fischer et al. 2007; Evans et al. 2013; Habel et al. 2019). Simplification of

\footnotetext{
*Correspondence: pushpa.soti@utrgv.edu

${ }^{4}$ School of Earth, Environment, and Marine Sciences, University of Texas-Rio Grande Valley, Edinburg, TX 78539, USA

Full list of author information is available at the end of the article
}

agricultural landscapes has caused a significant decline in flowering plants, which in turn has impacted the pollinator populations (Blaauw et al. 2014). With the alarming decline in insect populations (Sánchez-Bayo and Wyckhuys, 2019; Hallmann et al. 2017; Leather 2017), planting native flowering plants has gained considerable interest among land managers and researchers (Kaiser-Bunbury et al. 2017; Morandin et al. 2013). Some of the widely used techniques include planting flowering species along field edges to attract beneficial insects and planting along highways as erosion control. Additionally,

\section{Springer Open}

(- The Author(s). 2021 Open Access This article is licensed under a Creative Commons Attribution 4.0 International License, which permits use, sharing, adaptation, distribution and reproduction in any medium or format, as long as you give appropriate credit to the original author(s) and the source, provide a link to the Creative Commons licence, and indicate if changes were made. The images or other third party material in this article are included in the article's Creative Commons licence, unless indicated otherwise in a credit line to the material. If material is not included in the article's Creative Commons licence and your intended use is not permitted by statutory regulation or exceeds the permitted use, you will need to obtain permission directly from the copyright holder. To view a copy of this licence, visit http://creativecommons.org/licenses/by/4.0/. 
restoring reclaimed agricultural land with native plants is becoming popular. In most of these cases, seeds are directly sowed into the soil. However, several environmental factors influence the germination and establishment of native plants in the heavily degraded soils and result in a high failure rate (Nevill et al. 2018), and there is limited information available on collecting, cleaning, and quality testing of native plant seeds (Frischie et al. 2020). Factors such as compacted soils, low nutrient and moisture, and lack of soil biota, which can potentially break the seed dormancy or pathogens that cause decay of seeds, can have significant impacts on the seed germination and growth. While land mangers focus on the soil chemical and physical characteristics, soil biology has remained largely unexplored in habitat restoration (Harris 2009; Docherty et al. 2019).

Seed burial depth and native soil microbes are some of the important factors that influence seed germination, growth, and survival (Benvenuti, 2003; Sarmiento et al. 2017; Ye et al. 2019). Seed burial depth can affect seed growth, survival, and overall germination process. Fatal germination may occur where seeds may germinate at depths they are unable to reach the surface (Davis et al. 2007) or meet physical barriers such as soil type, where obstruction in the emergence path can result in unsuccessful establishment (Gardarin et al. 2010; Benvenuti 2003). Similarly, soil microbes also play a key role in seed germination and growth. Biological soil crusts are known to have positive effects on the emergence and survival of native plants in arid regions (Song et al. 2017) and dry land restoration (Muñoz-Rojas et al. 2018). The growing understanding of soil microbe and plant relationships shows diverse interactions that improve plant health, where beneficial microbes aid in the seed germination, seedling survival, growth, increase seed output; protect from harmful pathogens; and reduce environmental stress (Ashraf and Foolad 2005; Compant et al. 2010).

In this study, we analyzed the impact of native soil microbes, which the plants have coevolved, and seed burial depth on the germination and growth of two short lived, native wildflower species, Ratibida columnifera (Nutt.) (Mexican Hat) and Verbesina encelioides (Cav.) (cowpen daisy), in south Texas, the Lower Rio Grande Valley (LRGV). The LRGV has semi-arid subtropical climate. Summers are long and hot with average high temperatures $35^{\circ} \mathrm{C}$, and winters are mild with only occasional frost or freezing (Adhikari and White, 2014). The average annual rainfall is $682 \mathrm{~mm}$ with majority of precipitation occurring during September and October (Eddy and Judd 2003). Soils here are poor in nitrogen and high in $\mathrm{pH}$ and salinity.

The LRGV region is likely to experience lower precipitation and higher temperatures in the future (Hernandez and Uddameri 2014; Jiang and Yang 2012), calling for improved germination to maintain and restore the remaining native habitat (Leslie Jr 2016). Both $R$. columnifera and $V$. encelioides are popular for their role in attracting native pollinators and predators and their ability to optimize disturbed soils (Soti et al. unpublished data). Recently, these plants, along with other native plants, are being displaced by exotic invasive grasses such as Pennisetum ciliare (buffelgrass), Dichanthium annulatum (Kleberg's bluestem), and Megathyrsus maximus (guinea grass). We conducted a series of three experiments to test the hypotheses that (i) treating the seeds with the native soil microbial wash improves the germination rate of the two plant species; (ii) microbial wash treatment increases the growth and reproduction; and (iii) seed germination is influenced by the seed burial depth.

\section{Materials and methods}

Seed and native soil source

Seeds of both plants $R$. columnifera and $V$. encelioides were collected from a certified organic vegetable farm, left fallow for a year, in Edinburg, Texas, in the spring of 2019. The seed heads were removed, stored in a paper bag, separated, sorted, and dried to be stored long term ( $>1$ year). During the summer of 2020, topsoil $(0-6 \mathrm{~cm})$ was collected from the same farm and was used for both the microbial wash extraction and for the growth chamber experiments.

\section{Experiment 1: influence of native soil microbes on seed germination}

The common soil microbial wash method was used to treat the seeds with the native soil microbiome following the method by Howard et al. (2017). The microbial wash was prepared by mixing $40-\mathrm{g}$ soil in a $160 \mathrm{~mL}$ solution of $0.85 \% \mathrm{NaCl}$ using a magnetic stirrer at $180 \mathrm{rpm}$ for $10 \mathrm{~min}$. To remove the soil particles in the solution, the mixture was vacuum filtered using Whatman \#1 filter papers. To isolate the microbial fraction and remove water-soluble nutrients and chemicals, the filtrate was then centrifuged at $3000 \mathrm{rpm}$ for $30 \mathrm{~min}$ in $50-\mathrm{ml}$ centrifuge tubes, and the supernatant was discarded. We extracted the pelleted microorganisms at the bottom of the centrifuge tube in $200 \mathrm{ml} 0.85 \% \mathrm{NaCl}$ solution.

Two hundred seeds of both $R$. columnifera and $V$. encelioides were randomly selected and sterilized with a solution of 1:1 deionized (DI) water: bleach $(6 \% \mathrm{NaClO})$ (Great Value, Bentonville, AK) and rinsed three times with DI water. Of these, half of the seeds of each species were randomly selected and soaked in the microbial wash extracted from farm soil, and the other half were soaked in DI water for $5 \mathrm{~h}$. The treated seeds were randomly placed in sterile Petri dishes lined with wet paper 
napkins (10 seeds per dish, with 10 replications) for each treatment. All plates were kept under a controlled light setting in room temperature $\left(24-26^{\circ} \mathrm{C}\right)$ in the Weed Ecology Lab at UTRGV for 14 days. The total number of germinated seeds was counted every other day. Seeds were considered germinated when the radicle was visible and nonviable when soft and moldy (Coffey and Krikman 2006). We calculated germination rate (\%) as done by Wu et al. (2016) for both the species:

$$
\% \text { Germination }=\frac{\mathrm{Gt}}{T} \times 100
$$

where Gt is the number of germinated seeds within 14 days and $T$ is the total number of seeds.

\section{Experiment 2: influence of native soil microbes on growth and biomass allocation}

To determine the influence of native microbes on plant growth and biomass allocation, the randomly selected seedlings from experiment 1 were planted in pots filled with native sterilized (autoclave) and potting media (3:1) mix. The microbial treatment seedlings received an additional $1 \mathrm{ml}$ of microbial wash extract prepared on the same day following the modified protocol in experiment 1. The microbial wash used in this experiment was not passed through the filter paper to allow arbuscular mycorrhizal fungi (AMF) propagules to pass through. Each treatment was replicated 7 times for each species with a total of 14 pots per plant species. The pots were placed in a growth chamber $\left(28^{\circ} \mathrm{C}, 12 \mathrm{~h}\right.$ light/dark cycle) and watered every other day with $100 \mathrm{ml}$ DI water to maintain $10 \%$ soil moisture. Plants in both treatments were grown for 6 weeks and terminated when $V$. encelioides plants started to produce flowers. The plants were destructively harvested and separated into leaves, flowers, stem, and roots. Area of the leaves was determined using a bench-top leaf area meter (LI-3100C, LI-COR Biotechnology, Lincoln, Nebraska, USA). The roots were washed with tap water, and $251.5-\mathrm{cm}$ root fragments were separated for AMF analysis. All plant parts were then placed in separate paper bags and dried $\left(65^{\circ} \mathrm{C}\right)$ in an oven to constant temperature for $78 \mathrm{~h}$. After drying, the plant parts were weighed to calculate the total biomass, flower mass ratio (flower biomass/total biomass) (FMR), leaf mass ratio (leaf biomass/ total biomass) (LMR), stem mass ratio (stem biomass/total biomass) (SMR), root mass ratio (root biomass/total biomass) (RMR), and specific leaf area (leaf area/leaf biomass) (SLA). To determine the root mycorrhizal fungi (AMF), dark septate endophyte (DSE) and colonization, the roots were stained following the destructive root staining method (Vierheiling et al. 2005). Roots were cleared by boiling in $15 \% \mathrm{KOH}$ at $70{ }^{\circ} \mathrm{C}$ for $2 \mathrm{~h}$, rinsed twice with water, bleached with ammoniated $\mathrm{H}_{2} \mathrm{O}_{2}$, and acidified with $1 \mathrm{~N} \mathrm{HCl}$. Staining was done using Sheaffer black ink in acidified glycerol at $80{ }^{\circ} \mathrm{C}$ for $20 \mathrm{~min}$. The stained roots were washed with tap water and acidified with $25 \%$ acetic acid for $10 \mathrm{~min}$. The root fragments were then mounted parallel on slides in lactoglycerol covered with coverslip and examined for fungal structures at $\times 100$ magnification. Evidence of AMF colonization was based on the presence of intraradical hyphae, arbuscules, or vesicles on the root fragments, and the evidence of dark septate endophyte (DSE) colonization was based on the presence of hyphae or microsclerotia. Since most root fragments had both AMF and DSE, both were counted together as endophytes.

\section{Experiment 3: influence of seeding depth on seed germination and growth}

To examine the impact of seeding depth on the germination and plant growth, we sterilized the seeds as done in experiment 1 . We sowed 5 seeds each of both the plant species at 3 different depths, $2 \mathrm{~cm}, 6 \mathrm{~cm}$, and 12 $\mathrm{cm}$ in 12-cm high pots filled with 3:1 native soil commercial potting media mix. We had 5 replications of each depth for both plant species with a total of 15 pots per plant species and a total of 25 seeds per seeding depth. We randomly stored all bioassays in an environmental growth chamber $\left(28^{\circ} \mathrm{C}, 12 \mathrm{~h}\right.$ light/dark cycle) and watered every other day with $100 \mathrm{ml}$ DI water to maintain $10 \%$ soil moisture. We monitored germination of seeds for 14 days. Since there was no germination of seeds of $V$. encelioides at $6 \mathrm{~cm}$ and $12 \mathrm{~cm}$, not further measurements were done after 14 days. $R$. columnifera was grown for 6 weeks and destructively harvested when the plants started flowering. The plants were dried in an oven at $65^{\circ} \mathrm{C}$ for $78 \mathrm{~h}$ to a constant weight, and the total biomass was measured.

\section{Statistical analysis}

We used the statistical software JMP to analyze the data collected from these experiments. We used two-way ANOVA to determine the impact of microbial treatment on the seed germination. One-way ANOVA was used to compare the difference in total biomass accumulation, biomass allocation, specific leaf area, and the number of flowers per plant in the two treatments for both the plant species. $T$-test was done to compare the total biomass of $R$. columnifera plants at $2-\mathrm{cm}$ and $6-\mathrm{cm}$ depth. Correlation analysis was done to determine the correlation between root endophyte presence and plant growth parameters. The difference was considered significant if $P \leq 0.05$.

\section{Results}

Overall, our results show a mixed effect of microbial treatment on seed germination and growth in the two wildflower species (Fig. 1). The germination rate of $R$. 


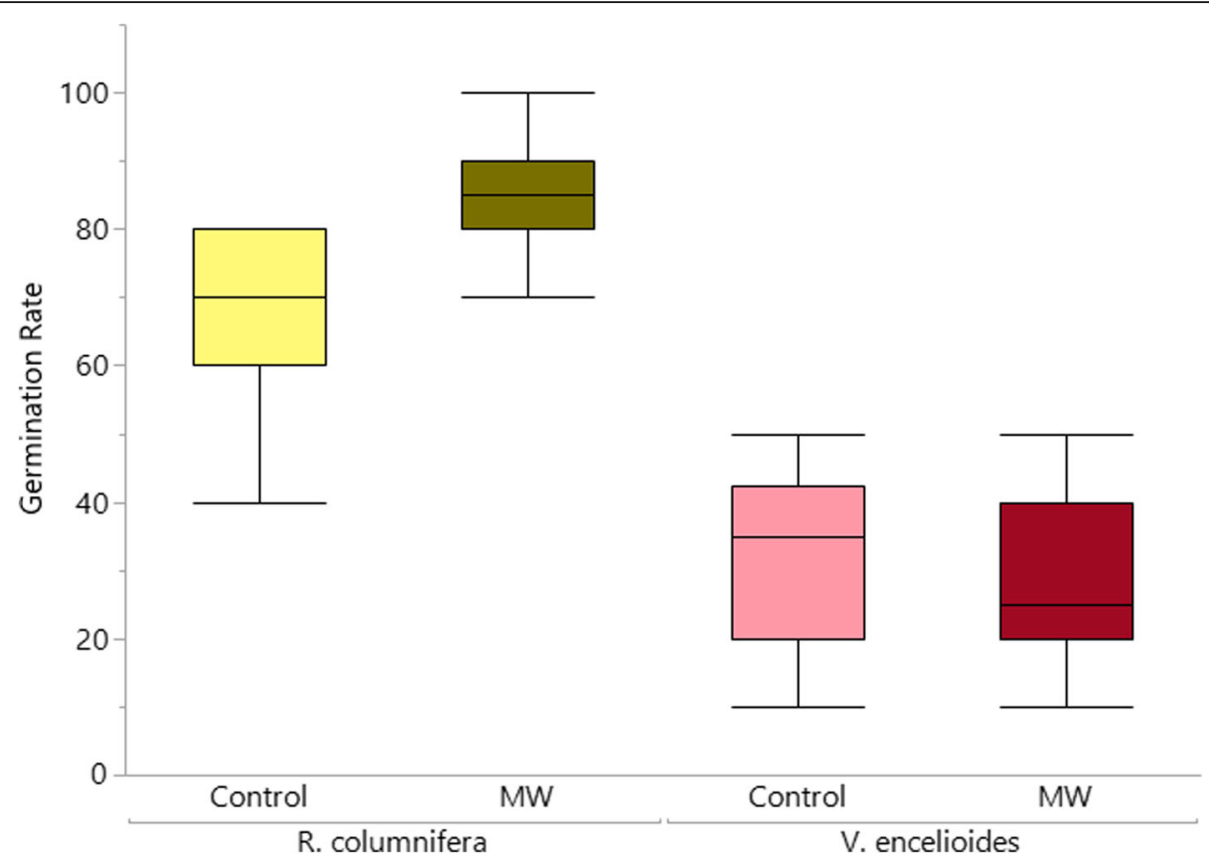

Fig. 1 The total germination rate for $V$. encelioides and $R$. columnifera seeds treated with a microbial wash (MW) and without any treatment (control) at the end 14-day period

columnifera was significantly higher than that of $V$. encelioides $(P<0.0001)$. On average, $R$. columnifera had more than $75 \%$ germination rate while $V$. encelioides had about $30 \%$ germination rate.

The two species had different response to microbial wash treatment, while the germination rate in $V$. encelioides was not influenced by the microbial wash treatment $R$. columnifera seeds treated with microbial wash had a significantly higher germination rate $(P=0.004)$. In addition, seeds of $R$. columnifera germinated earlier than $V$. encelioides. While the $R$. columnifera seeds started germinating at day $4, V$. encelioides seeds started germinating at day 6 (Fig. 2).

While the total biomass was not influenced by the microbial wash treatment, there was a significant difference in the biomass allocation strategy between the control and microbial wash treatment for both the species (Table 1). LMR was significantly higher in microbial

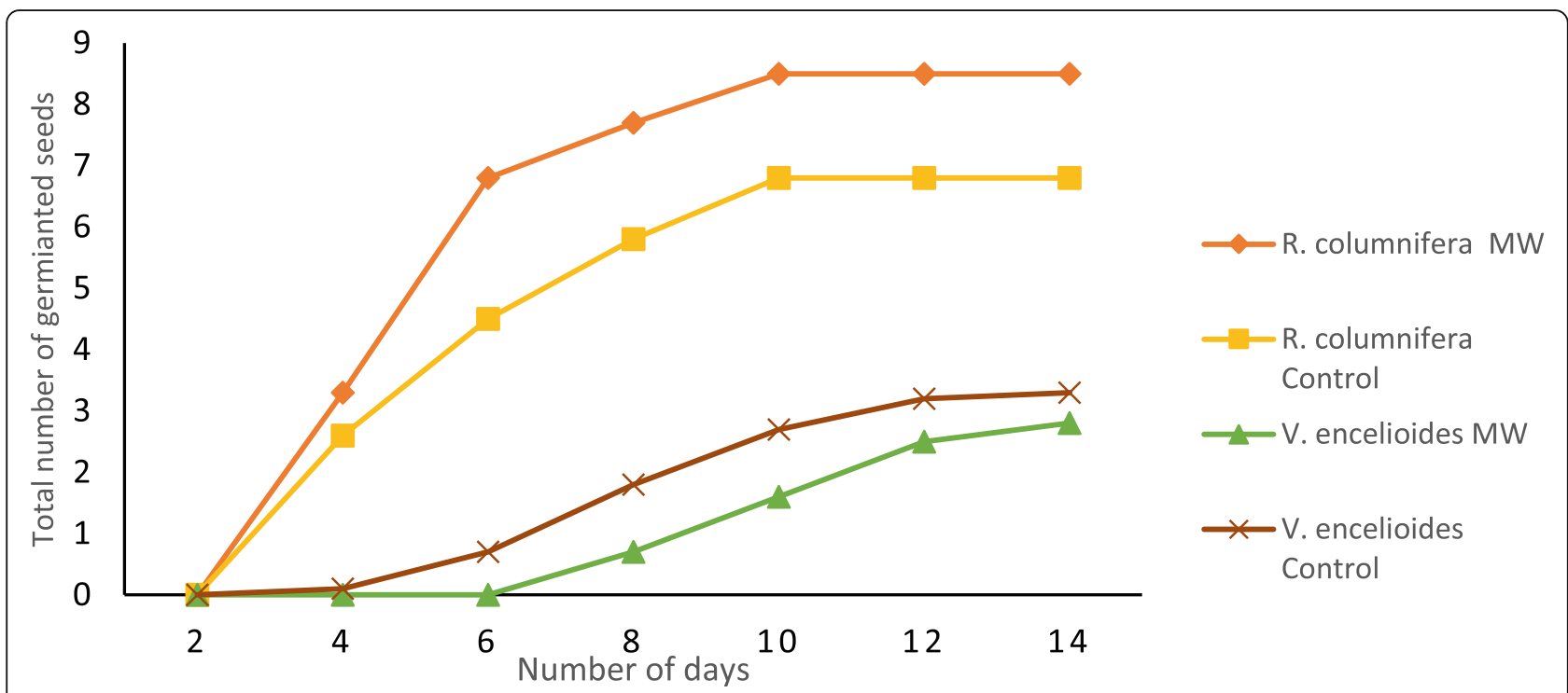

Fig. 2 The total germination rate for $V$. encelioides and $R$. columnifera treated with a microbial wash (MW) and without any treatment (control) over the 14-day period 
Table 1 Difference in plant growth and biomass allocation between the control and microbial wash (MW) treatments in $\mathrm{V}$. encelioides and $R$. columnifera

\begin{tabular}{llllll}
\hline & \multicolumn{2}{l}{ V. encelioides } & & \multicolumn{2}{l}{$\boldsymbol{R}$. columnifera } \\
\cline { 2 - 3 } & Control & MW & & Control & MW \\
\hline Total biomass $(\mathrm{g})$ & $6.31 \mathrm{a}$ & $6.81 \mathrm{a}$ & & $1.35 \mathrm{a}$ & $1.44 \mathrm{a}$ \\
LMR & $0.33 \mathrm{~b}$ & $0.41 \mathrm{a}$ & $0.53 \mathrm{a}$ & $0.37 \mathrm{~b}$ \\
SMR & $0.41 \mathrm{a}$ & $0.30 \mathrm{~b}$ & $0.21 \mathrm{~b}$ & $0.35 \mathrm{a}$ \\
RMR & $0.14 \mathrm{a}$ & $0.13 \mathrm{a}$ & $0.26 \mathrm{a}$ & $0.28 \mathrm{a}$ \\
FMR & $0.12 \mathrm{~b}$ & $0.15 \mathrm{a}$ & 0.00 & 0.00 \\
SLA & $118.39 \mathrm{a}$ & $99.91 \mathrm{a}$ & $91.76 \mathrm{a}$ & $95.23 \mathrm{a}$ \\
Flowers/plant & $3.00 \mathrm{~b}$ & $5.00 \mathrm{a}$ & 0.00 & 0.00 \\
\hline
\end{tabular}

Numbers in columns with similar letters represent no significant difference for each species at $P \leq 0.05$ )

wash compared to control $(P=0.025)$ in $V$. encelioides, while for $R$. columnifera control plants had higher LMR $(P=0.0002)$. SMR was significantly higher in control than microbial wash in $V$. encelioides $(P=0.001)$ while $R$. columnifera had higher SMR in microbial wash plants $(P<0.0001)$. Similarly, FMR was also higher in microbial wash plants $(P=0.02)$ in $V$. encelioides. Total number of flowers produced was higher in microbial wash $(P=$ $0.003)$ of $V$. encelioides where $R$. columnifera plants did not produce any flowers during the 6-week period. Correlation analysis showed that there was positive correlation between the root endophyte colonization and number of flowers $(r=0.53, P=0.004)$ and FMR $(r=$ $0.41, P=0.029)$ in $V$. encelioides. There was no significant difference in the RMR or LSA between the control and microbial wash treatment for both study species.

Roots of both plant species were colonized by AMF and DSE (Fig. 3). DSE was dominant in the roots of both plant species. There was a significant difference in the root colonization by endophytes in two plants $(P=$ 0.004); $V$. encelioides roots had almost the double rate of colonization compared to $R$. columnifera plants (58\% and $30 \%$ respectively).

The two plants responded differently to the seeding depths. R. columnifera seeds planted at $2 \mathrm{~cm}$ and 6 $\mathrm{cm}$ germinated but there is no germination at $12 \mathrm{~cm}$. There was no significant difference in the germination rate at both depths, $76 \%$ at $2 \mathrm{~cm}$ and $72 \%$ at $6 \mathrm{~cm}$. However, for $V$. encelioides, seeds germinated only 2 $\mathrm{cm}$ (germination rate $40 \%$ ), and there was no germination at $6 \mathrm{~cm}$ and $12 \mathrm{~cm}$.

\section{Discussion}

Research has shown that for successful habitat restoration, it is important to integrate both native plants and soil microbe restoration strategies (Heneghan et al. 2008; Docherty et al. 2019). Recently, there has been an increase in use of commercial microbial inoculants in thorn forest restoration along the Lower Rio Grande, but these have not resulted in any significant difference in the establishment and growth of native plants (P. Soti, personal communication). While the results are species specific, our results show that treating seeds with native soil microbes support increased germination and growth of wildflowers. Treating the seeds with native microbes has been proven to significantly increase seed germination rate, plant biomass, seed yield, and resistance to abiotic stress in agricultural crops (Mastouri et al. 2010; Wu et al. 2016; Rocha et al. 2019).

In our study, microbial treatment did not result in the increase in total biomass; however, there was a significant difference in germination rate, biomass allocation, and number of flowers produced in between the treated and untreated plants. Surprisingly, the microbial wash treatment had opposite results in the two plants studied. $R$. columnifera seeds treated with microbial treatment had higher germination rate compared to the control. Soil microbes are reported to improve germination rate via the production of plant growth hormones (Wu et al. 2016). While $V$. encelioides plants in the microbial wash treatment had significantly higher LMR compared to the control, $R$. columnifera plants had significantly higher LMR in the control. The plants also allocated biomass differently to the stems; $V$. encelioides in microbial treatment allocated lower biomass to the stem compared to control. On the other hand, $R$. columnifera plants in microbial treatment allocated higher biomass to the stem compared to the control. The different response to microbial treatment in germination and growth seen in the two plants could be because the plants were in different stages of growth. While the $V$. encelioides plants took time to germinate, but after germination, they grew rapidly and produced flowers whereas $R$. columnifera plants germinated early but had not started flowering in 6 weeks.

There was a difference in the endophyte colonization in the two plant species. Roots of both plants treated with microbial wash had both AMF and DSE in them. However, DSE structures (hyphae or microsclerotia) were more prominent. DSE has been reported in the roots of plants adapted to water stress (Knapp et al. 2012; Li et al. 2018). Both the plants used in our study are well adapted in the semi-arid regions of south Texas. Further analysis is needed to identify these endophytes and to determine their roles in the growth of native species in this region for successful habitat restoration with native species. Environmental factors such as drought and other confounding variables such as chemotaxis and phytotoxins can influence the effect these microbes have on seeds and seedling growth (Kremer 1993). There is need to identify the microbial community the plants have evolved with and their roles if we are to 

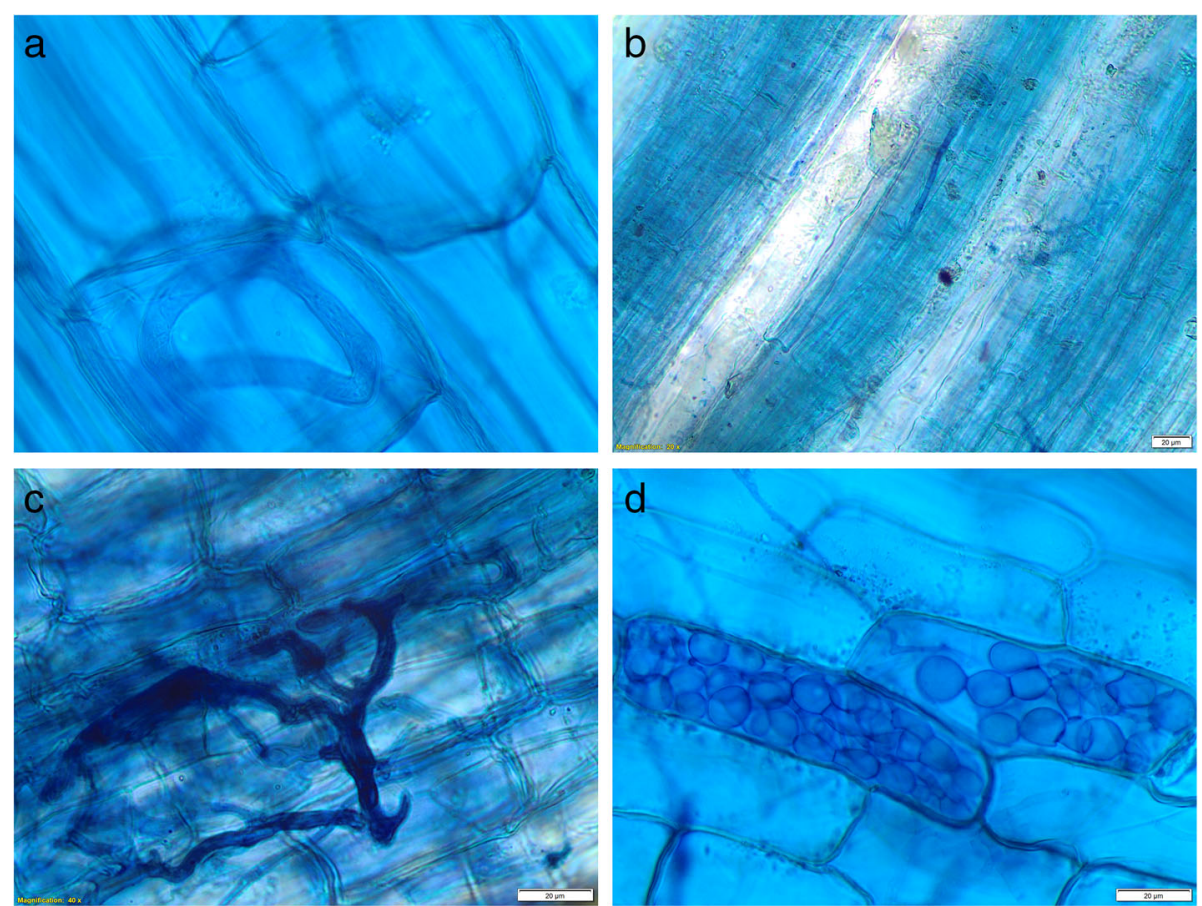

Fig. 3 Root colonization by $\operatorname{AMF}(\mathbf{a}, \mathbf{c})$ and DSE (b, d) in the roots of R. columnifera (top) and V. encelioides (bottom) plants treated with microbial wash

successfully restore belowground community and thus the aboveground plant community.

Similarly, species-specific results were seen for seeding depth. $R$. columnifera seeds, which are smaller than $V$. encelioides seeds, germinated from $2 \mathrm{~cm}$ and $6 \mathrm{~cm}$, while $V$. encelioides seeds germinated at $2 \mathrm{~cm}$ depth only. However, after germination, $V$. encelioides grew much faster than $R$. columnifera. Differences in germination rate and plant vigor due to seed size have been reported in previous studies (Souza \& Fagundes 2014). Our results show that seeds may not germinate and become dormant if they are planted or pushed more than 3-4 $\mathrm{cm}$ deeper into the soil. Furthermore, different seeds germinate at different depths; thus, sowing wildflower and native plant mixes has the potential to bury seeds deeper in the soil, thus reducing size of seed bank by killing sensitive native seeds, dormant in the soil, or potentially burying seeds deeper into the earth (Grass et al. 2016). Site preparation and seed delivery are critical in seed-based restoration projects (Shaw et al. 2020). Thus, when using seed mixes for restoration, it is important to consider both soil biology and environmental factors to avoid germination and establishment failures (Pedrini et al. 2020).

The Tamaulipan thornscrub, a subtropical, semi-arid vegetation type occurring in either side of the Rio Grande, provides a unique habitat for both plants and animals. Clearing the shrubland for agriculture has resulted in a significant alteration of the patterns and processes of this ecoregion. Being in the subtropics, this region is projected to experience lower precipitation and higher temperatures (Jiang and Yang 2012; Hernandez and Uddameri 2014), further endangering the plants and animals. Thus, there is a need for restoring the habitats with the locally adapted plant materials or local ecotypes to maintain the native habitat that remains and restore abandoned agricultural fields (Leslie Jr 2016). The success of habitat restoration projects will largely depend on the effective seed use (Pedrini et al. 2020). Successful use of beneficial microbes to enhance seed germination and seedling survival is site and plant species dependent.

\section{Conclusions}

Overall, our results show that native soil microbial communities have the potential to influence the seed germination and growth of wildflowers. Our results also indicate the importance of specific seeding depth with showing wildflowers seeds for habitat restoration. This result is particularly important when preparing wildflower seed mixes to ensure high germination rate. Further analysis of the soil microbes is needed to identify the microbiota in the soil for effective use of natives as well as the selection of commercial microbial inoculant types. 


\section{Abbreviations}

AMF: Arbuscular mycorrhizal fungi; DSE: Dark septate endophyte; DI: Deionized; FMR: Flower mass ratio; LMR: Leaf mass ratio; LRGV: Lower Rio Grande Valley; MW: Microbial wash; RMR: Root mass ratio; SLA: Specific leaf area; SMR: Stem mass ratio

\section{Acknowledgements}

We thank the UTRGV High Scholars Program for providing the research experience opportunity to high school students D. Barrera and J. Luera. We thank graduate student Mandip Tamang for his assistance in the experiment set-up and Dr. Alexis Racelis for allowing us to use the plant growth chambers in his lab.

\section{Authors' contributions}

Daniela Barrera and Juan Luera contributed to the experimental design, writing the manuscript, and data analysis. Kaitlynn Lavallee collected the seeds, contributed to the interpretation of data analysis, and prepared the overall manuscript. Pushpa Soti developed the experimental design, conducted the experiment, and made final revisions to the manuscript. The authors read and approved the final manuscript.

\section{Funding}

N/A

\section{Availability of data and materials}

The datasets used and/or analyzed during the current study are available from the corresponding author on reasonable request.

\section{Ethics approval and consent to participate}

Not applicable.

\section{Consent for publication}

Not applicable

\section{Competing interests}

The authors declare no competing interests.

\section{Author details}

${ }^{1}$ Mathematics and Science Academy, University of Texas-Rio Grande Valley, Edinburg 78539, USA. ${ }^{2}$ Sharyland Pioneer High School, Mission, TX 78573, USA. ${ }^{3}$ Department of Biology, University of Texas-Rio Grande Valley, Edinburg, TX 78539, USA. ${ }^{4}$ School of Earth, Environment, and Marine Sciences, University of Texas-Rio Grande Valley, Edinburg, TX 78539, USA.

\section{Received: 12 October 2020 Accepted: 10 February 2021}

Published online: 06 March 2021

\section{References}

Adhikari A, White JD (2014) Plant water use characteristics of five dominant shrub species of the Lower Rio Grande Valley, Texas, USA: implications for shrubland restoration and conservation. Conserv Physiol 2(1):cou005

Ashraf M, Foolad MR (2005) Pre-sowing seed treatment-a shotgun approach to improve germination, plant growth, and crop yield under saline and nonsaline conditions. Adv Agron 88:223-271

Benvenuti S (2003) Soil texture involvement in germination and emergence of buried weed seeds. Agron J 95(1):191-198

Biesmeijer JC, Roberts SP, Reemer M, Ohlemüller R, Edwards M, Peeters T et al (2006) Parallel declines in pollinators and insect-pollinated plants in Britain and the Netherlands. Science 313(5785):351-354

Blaauw BR, Isaacs R (2014) Larger patches of diverse floral resources increase insect pollinator density, diversity, and their pollination of native wildflowers. Basic Appl Ecol 15(8):701-711

Coffey KL, Kirkman LK (2006) Seed germination strategies of species with restoration potential in a fire-maintained pine savanna. Nat Areas J 26(3): 289-299

Compant S, Clément C, Sessitsch A (2010) Plant growth-promoting bacteria in the rhizo- and endosphere of plants: their role, colonization, mechanisms involved and prospects for utilization. Soil Biol Biochem 42(5):669-678

Davis AS, Renner KA (2007) Influence of seed depth and pathogens on fatal germination of velvetleaf (Abutilon theophrasti) and giant foxtail (Setaria faberi). Weed Sci 55(1):30-35
Docherty KM, Gutknecht JL (2019) Soil microbial restoration strategies for promoting climate-ready prairie ecosystems. Ecol Appl 29(3):e01858

Eddy MR, Judd FW (2003) Phenology of Acacia berlandieri, A. minuata, A. rigidula, A. schaffneri, and Chloroleucon ebano in the Lower Rio Grande Valley of Texas during a drought. Southwest Nat 48(3):321-332

Evans DM, Pocock MJ, Memmott J (2013) The robustness of a network of ecological networks to habitat loss. Ecol Lett 16(7):844-852

Fischer J, Lindenmayer DB (2007) Landscape modification and habitat fragmentation: a synthesis. Global Ecol Biogeogr 16(3):265-280

Frischie S, Miller AL, Pedrini S, Kildisheva OA (2020) Ensuring seed quality in ecological restoration: native seed cleaning and testing. Restor Ecol 28:S239$\$ 248$

Gardarin A, Dürr C, Colbach N (2010) Effects of seed depth and soil aggregates on the emergence of weeds with contrasting seed traits. Weed Res 50(2):91101

Grass JL, Tjelmeland AD, Smith FS, Mitchell SL, Rideout-Hanzak S, Lloyd-Reilley J et al (2016) Effects of depth and duration of burial on tanglehead (Heteropogon contortus) seed viability and germination in southern Texas. Ecol Restor 34(1):7-10

Habel JC, Ulrich W, Biburger N, Seibold S, Schmitt T (2019) Agricultural intensification drives butterfly decline. Insect Conserv Divers 12(4):289-295

Hallmann CA, Sorg M, Jongejans E, Siepel H, Hofland N, Schwan H et al (2017) More than 75 percent decline over 27 years in total flying insect biomass in protected areas. PLoS One 12(10):e0185809

Harris J (2009) Soil microbial communities and restoration ecology: facilitators or followers? Science 325(5940):573-574

Heneghan L, Miller SP, Baer S, Callaham MA Jr, Montgomery J, Pavao-Zuckerman $M$ et al (2008) Integrating soil ecological knowledge into restoration management. Restor Ecol 16(4):608-617

Hernandez EA, Uddameri V (2014) Standardized precipitation evaporation index (SPEI)-based drought assessment in semi-arid south Texas. Environ Earth Sci 71(6):2491-2501

Howard MM, Bell TH, Kao-Kniffin J (2017) Soil microbiome transfer method affects microbiome composition, including dominant microorganisms, in a novel environment. FEMS Microbiol Lett 364(11):fnx092

Jiang X, Yang ZL (2012) Projected changes of temperature and precipitation in Texas from downscaled global climate models. Climate Res 53(3):229-244

Kaiser-Bunbury CN, Mougal J, Whittington AE, Valentin T, Gabriel R, Olesen JM, Blüthgen N (2017) Ecosystem restoration strengthens pollination network resilience and function. Nature 542(7640):223-227

Knapp DG, Pintye A, Kovács GM (2012) The dark side is not fastidious-dark septate endophytic fungi of native and invasive plants of semiarid sandy areas. PLoS One 7(2):e32570

Kremer RJ (1993) Management of weed seed banks with microorganisms. Ecol Appl 3(1):42-52

Leather SR (2017) "Ecological Armageddon" - more evidence for the drastic decline in insect numbers. Ann Appl Biol 172(1):1-3

Leslie DM Jr (2016) An international borderland of concern: conservation of biodiversity in the Lower Rio Grande Valley (No. 2016-5078). US Geological Survey, Reston

Li X, He X, Hou L, Ren Y, Wang S, Su F (2018) Dark septate endophytes isolated from a xerophyte plant promote the growth of Ammopiptanthus mongolicus under drought condition. Sci Rep 8:7896

Mastouri F, Björkman T, Harman GE (2010) Seed treatment with Trichoderma harzianum alleviates biotic, abiotic, and physiological stresses in germinating seeds and seedlings. Phytopathology 100(11):1213-1221

Morandin LA, Kremen C (2013) Hedgerow restoration promotes pollinator populations and exports native bees to adjacent fields. Ecol Appl 23(4): 829-839

Muñoz-Rojas M, Chilton A, Liyanage GS, Erickson TE, Merritt DJ, Neilan BA, Ooi MKJ (2018) Effects of indigenous soil cyanobacteria on seed germination and seedling growth of arid species used in restoration. Plant Soil 429(1-2):91-100

Nevill PG, Cross AT, Dixon KW (2018) Ethical seed sourcing is a key issue in meeting global restoration targets. Curr Biol 28(24):R1378-R1379

Pedrini S, Balestrazzi A, Madsen MD, Bhalsing K, Hardegree SP, Dixon KW, Kildisheva OA (2020) Seed enhancement: getting seeds restoration-ready. Restor Ecol 28:S266-\$275

Rocha IDS, Ma Y, Souza-Alonso P, Vosátka M, Freitas H, Oliveira RS (2019) Seed coating: a tool for delivering beneficial microbes to agricultural crops. Front Plant Sci 10:1357 
Sánchez-Bayo F, Wyckhuys KA (2019) Worldwide decline of the entomofauna: a review of its drivers. Biol Conserv 232:8-27

Sarmiento C, Zalamea PC, Dalling JW, Davis AS, Stump SM, U'Ren JM, Arnold AE (2017) Soilborne fungi have host affinity and host-specific effects on seed germination and survival in a lowland tropical forest. Proc Nat Acad Sci 114(43):11458-11463

Shaw N, Barak RS, Campbell RE, Kirmer A, Pedrini S, Dixon K, Frischie S (2020) Seed use in the field: delivering seeds for restoration success. Restor Ecol 28: S276-S285

Song G, Li X, Hui R (2017) Effect of biological soil crusts on seed germination and growth of an exotic and two native plant species in an arid ecosystem. PLoS One 12(10):e0185839

Souza ML, Fagundes M (2014) Seed size as key factor in germination and seedling development of Copaifera langsdorffii (Fabaceae). Am J Plant Sci 5: 2566-2573

Vierheilig H, Schweiger P, Brundrett M (2005) An overview of methods for the detection and observation of arbuscular mycorrhizal fungi in roots. Physiol Plant 125(4):393-404

Wu YN, Feng YL, Paré PW, Chen YL, Xu R, Wu S et al (2016) Beneficial soil microbe promotes seed germination, plant growth and photosynthesis in herbal crop Codonopsis pilosula. Crop Pasture Sci 67(1):91-98

Ye X, Li L, Baskin CC, Baskin JM, Du J, Huang Z (2019) Sand burial helps regulate timing of seed germination of a dominant herb in an inland dune ecosystem with a semiarid temperate climate. Sci Total Environ 680:44-50

\section{Publisher's Note}

Springer Nature remains neutral with regard to jurisdictional claims in published maps and institutional affiliations.

\section{Submit your manuscript to a SpringerOpen ${ }^{\circ}$ journal and benefit from:}

- Convenient online submission

- Rigorous peer review

- Open access: articles freely available online

- High visibility within the field

- Retaining the copyright to your article

Submit your next manuscript at $\boldsymbol{\nabla}$ springeropen.com 